\title{
P̈̈̈̈KIRJOITUS
}

\section{TOIMINTA OPETTAA, TOIMIEN OPPII}

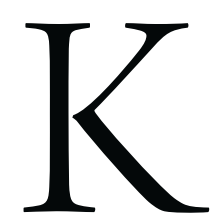

un oppiminen ja inhimillisen pääoman kasvattaminen on alettu nähdä tärkeäksi talouskasvun välineeksi, oppimisen tutkimus ja kehittäminen ovat houkutelleet monenlaista yrittäjää. Oppimiskäsitysten moninaisuus juontuu osittain myös siitä, että oppimisen edistämisopeista on tullut bisnestä.

Kun oppiminen käsitteenä vapautui oppilaitosten monopolista työelämään, arkipäivään ja kaikille elämän alueille, kilpailu oppimisen määritelmistä ja menetelmistä sai uutta vettä myllyyn. Muutosta voi verrata mihin hyvänsä julkisen vallan monopolin purkautumiseen seurauksineen. Syntyi oppimiskäsitteiden ja -menetelmien markkinat. Koulutusteollisuus suorastaan pursuaa mitä erilaisimpia oppimisen oppeja. Koulutuskonsultit elävät siitä, että saavat uskottavasti tarjottua omaa 'oppimisbrändiään' ratkaisuksi työelämän ongelmiin ja tuottavuuden edistämiseksi. Samaa vikaa on myös tieteenharjoittajien piirissä, missä tutkijat ympäri maailmaa pyrkivät erottautumaan luomalla uusia oppimisteorioita iskevine muotikäsitteineen.

PETER JARVIS on useissa kirjoissaan ja kirjoituksissaan pyrkinyt purkamaan aikuisten oppimiseen liitettyä mystiikkaa. Ihminen oppii kaiken aikaa kaikissa toimintaympäristöissä. Toimiva ihminen on jatkuvasti oppiva ihminen. 'Oppimaton ihminen' on käsitteellinen paradoksi.
Enimmäkseen oppiminen pohjautuu siihen, että yksilö koettaa tulla toimeen ympäristössään, joko sopeutuen siihen tai yrittäen muuttaa sitä. Sekä ympäristöön sopeutuminen että sen muuttaminen edellyttää uuden oppimista. Ympäristöistä tärkeimpiä ovat ne, joissa ihmiset hankkivat elantonsa, työelämä. Kun työt ja tehtävät muuttuvat kaiken aikaa, joudumme opettelemaan ja oppimiaan uusia tietoja, taitoja ja asennoitumista selvitäksemme muuttuvista tehtävistä. Palkkatyöhön perustuvassa yhteiskunnassa keskeinen sopeutumista ja oppimista edellyttävä areena ovat työmarkkinat, missä pääsystä työhön ja elannon syrjään kilpaillaan.

Työmarkkinoilla ihmiset saavat monenlaista oppia niin sanotusti kantapään kautta eli kokemuksesta. Globaalin työpaikkakilpailun oloissa myös suomalaiset työntekijät ovat saaneet kokea, että oman osaamisen jatkuva kehittäminen ei riitä työpaikan säilyttämiseksi. Kun Nokia ilmoitti helmikuun alussa 2012 lopettavansa matkapuhelinten valmistuksen Suomessa, ei ollut kysymys henkilöstön puutteellisesta osaamisesta. Matkapuhelinten valmistus Suomessa ei vain tuottanut enää riittävästi voittoa osakkeenomistajille.

Työpaikkansa lakkauttamisten jälkeen työtä vaille jääneet joutuvat asennoitumaan uudella tavalla tulevaisuuteensa. Kovimmin äkilliset irtisanomiset koettelevat työhönsä - ja työpaikkaansa - vahvasti 
sitoutuneita työntekijöitä. Kilpailu työstä on myös yksilötasolla globaalia, mutta nyt on monilla aloilla tultu tilanteeseen, missä työntekijät eivät enää voi oman osaamisen kehittämisellä vaikuttaa työnsä säilyttämiseen. Oman elämän koettu hallitsemattomuus lisääntyy. Ihmisten on opittava sopeutumaan uudenlaiseen ympäristöön. Se edellyttää myös arvostusten ja asenteiden muutosta vastaamaan paremmin nykyajan olosuhteita. Kun lopputili voi tulla milloin hyvänsä, työhön sitoutuminen alkaa olla työntekijöille vain haitaksi. On opittava löytämään mielekkyyttä jostain muusta kuin työnteosta. Olisiko sittenkin viisainta ottaa työnteko vain välttämättömänä pahana rahan hankkimiseksi? Ihmisten kaipaamat uudenlaiset yhteisöt löytynevät epävarmassa tulevaisuudessa jostakin työelämän ulkopuolelta. Ne saattavat muodostua työelämää vapaamman ja omaehtoisemman oppimisen ympäristöiksi.

MINNA MATTILA-AALTO tarkastelee tässä numerossa mielenkiintoisella tavalla leipäjonoyhteisöä informaalin oppimisen näkökulmasta: "Leipäjonoyhteisön sisältäpäin rakentuvassa käsikirjoituksessa yhteisön jäsenet nähdään lähtökohtaisesti aktiivisina toimijoina siitä huolimatta, että he ovat virallisessa kategorisoinnissa (pitkä)aikaistyöttömiä, jollakin tavoin sairaiksi diagnosoituja ja pienillä eläkkeillä kituuttavia syrjäytyneitä. Yhteisön jäsenyyttä ei tarjota leipäjonoyhteisön aloitteesta tai virallisen järjestelmän pakottamina, vaan ihmiset hakevat jäsenyyteen omista kokemuksistaan ja niistä kumpuavasta halusta olla mukana. Toiminnan motivaatiota ei rakenneta ulkoapäin muodollisten sopimusten tai sanktioiden varassa, vaan toimijat aktivoituvat haluksi muuttuneiden tarpeidensa ohjaamina." Missä on toimintaa, siellä opitaan.

VÄHÄVARAISTEN RUOKA-APUA on jaettu EU:ssa vuodesta 1987 alkaen. Viime vuosina ruokaa on jaettu noin 500 miljoonalla eurolla vuodessa. Koko EU:n alueella apu tavoittaa noin 18 miljoonaa köyhintä unionikansalaista. Kaksi kolmasosaa ruoka-avusta menee Italian, Puolan, Espanjan ja Ranskan köyhille. Suomen osuus budjetista oli viime vuonna 4,3 miljoonaa euroa. Elintarvikeapuna jaettavat tuotteet ovat hyvin säilyviä peruselintarvikkeita: vehnäjauhoa, sämpyläjauhoa, puurohiutaleita, makaronia, näkkileipää, hapankorppua, keksiä, mysliä, pastaa ja maitojauhetta.

Pitenevät leipäjonot saattavat ennakoida eurooppalaisen väestön polarisoitumista ja huono-osaisuuden laajenemista. Euroopan köyhyyden ja sosiaalisen syrjäytymisen torjunnan teemavuotena 2010 Euroopan unionin väestöstä 80 miljoonaa eli köyhyysrajan alapuolella. Helmikuun alussa julkaistut uudet tilastot eurooppalaisten elinoloista osoittavat, että teemavuoden jälkeen köyhien määrä on vain kasvanut. Köyhien ja syrjäytyneiden tai riskirajalla elävien eurooppalaisten määä on noussut 115 miljoonaan. Se merkitsee sitä, että lähes neljäsosa Euroopan Unionin väestöstä elää köyhyydessä tai on suistumassa köyhyyteen. Alle 17-vuotiaiden köyhyysriski on näitä keskimääräislukuja selvästi suurempi, mikä on tulevaisuutta ajatellen erittäin huono merkki. Se, että hallitukset kautta koko Euroopan karsivat julkista sektorin menoja, ennustaa huono-osaisille entistä kovempia aikoja.

Heikki Silvennoinen 